\title{
The Influence of Interleukin (IL)-1 $\beta$ and IL-6 and Tumour Necrosis Factor- $\alpha$ on Prostaglandin Secretion from Porcine Myometrium during the First Third of Pregnancy
}

\author{
Barbara Jana, Marlena Koszykowska, Aneta Andronowska \\ Division of Reproductive Endocrinology and Pathophysiology, Institute of Animal Reproduction \\ and Food Research of the Polish Academy of Sciences, Olsztyn, Poland
}

Received March 31, 2009

Accepted November 24, 2010

\begin{abstract}
The present study was undertaken to determine the effect of interleukin-1 $\beta$ (IL-1 $\beta$ ), interleukin-6 (IL-6) and tumour necrosis factor- $\alpha(\mathrm{TNF}-\alpha)$ on prostaglandin $(\mathrm{PG}) \mathrm{F}_{2 \alpha}$ and $\mathrm{PGE}_{2}$ secretion as well as cyclooxygenase-2 (COX-2) protein expression in myometrium collected on days 25,30 and 40 of pregnancy in pigs. Myometrial slices were incubated for $16 \mathrm{~h}$ with IL-1 $\beta$, IL-6 and TNF- $\alpha$ ( 1 or $10 \mathrm{ng} / \mathrm{ml}$ of medium) or two combinations of the three cytokines $(1 \mathrm{or} 10 \mathrm{ng} / \mathrm{ml}$ of each cytokine per combination). We demonstrated the stimulatory effect of IL-1 $\beta$ and IL-6 on $\mathrm{PGF}_{2 \alpha}$ and $\mathrm{PGE}_{2}$ secretion from myometrium collected on all examined days of pregnancy, excepting of influence of IL- 6 on release of $\mathrm{PGF}_{2 \alpha}$ by tissue from day 30 . In turn, TNF- $\alpha$ was able to stimulate only $\mathrm{PGE}_{2}$ secretion by myometrium of 40-day-pregnant gilts. The three cytokines applied in combination augmented release of $\mathrm{PGE}_{2}$ from myometrium collected on days 30 and 40 of pregnancy. Stimulation of $\mathrm{PGE}_{2}$ secretion by cytokines used individually was more frequent than that of $\mathrm{PGF}_{2 \alpha}$. Moreover, an enhancement in $\mathrm{PGF}_{2 \alpha}$ and/or $\mathrm{PGE}_{2}$ release was accompanied by an increase of $\mathrm{COX}-2$ protein expression. Our study shows the ability of cytokines to stimulate $\mathrm{PGF}_{2 \alpha}$ and $\mathrm{PGE}_{2}$ release by porcine myometrium from the first third of pregnancy. Obtained data suggest that locally PGs produced in myometrium influencing the uterine contraction activity may be important for the maintenance of myometrial quiescence during pregnancy and confirm also that the complex cytokine network is an important regulatory mechanism of PGs production during pregnancy.
\end{abstract}

Uterus, cytokines, $P G F_{2 \alpha}, P G E_{2}, C O X-2$, pigs

Prostaglandins $(\mathrm{PG}) \mathrm{F}_{2 \alpha}$ and $\mathrm{E}_{2}$ are of great significance for establishment and maintenance of pregnancy. They participate in several key processes such as implantation, decidualization, immunosuppression or dilatation of uterine arteries and initiation of parturition (Stanfield et al. 2003; Ashworth et al. 2006; Franczak et al. 2006). Moreover, PGs and their receptors play an important role in the maintenance of myometrial quiescence necessary for successful termination of pregnancy (Dong and Yallampalli 2000; Myatt and Lye 2004).

Interleukin (IL)-1, IL-6 and tumour necrosis factor- $\alpha$ (TNF- $\alpha$ ) are cytokines important for many pathological and physiological processes. They are synthesized and released not only by immunocompetent cells in response to lipopolysaccharides (LPS) (Kijubu et al. 1991; Lee et al. 1992) but also by many tissues and cell types including those of the female reproductive system (Hunt 1993). In pregnant females, cytokines are produced by bone marrow-derived cells, particularly macrophages (Hunt 1993), endometrium (Yu et al. 1998; Chabot et al. 2004), foetal membranes (Sato et al. 2001) and myometrium (Young et al. 2002). The local synthesis of IL-1, IL-6 and TNF- $\alpha$ in human (Kim et al. 1998), rodent (Sato et al. 2001) and porcine (Ross et al. 2003; Chabot et al. 2004) uterus fluctuates during gestation.

In vitro studies have shown that IL- 1 and TNF- $\alpha$ stimulated secretion of $\mathrm{PGE}_{2}$ and $\mathrm{PGF}_{2 \alpha}$ by myometrial cells of non-pregnant and pregnant women (Pollard and Mitchell 1996;

Phone: +48895393137

Fax: +48 895357421

E-mail: b.jana@pan.olsztyn.pl

http://www.vfu.cz/acta-vet/actavet.htm 
Rauk and Chiao 2000; Korita et al. 2004). These cytokines were found to stimulate the production of PGs by myometrial cells of non-pregnant women through increasing the expression of cyclooxygenase-2 (COX-2) and phospholipase $\mathrm{A}_{2}$ (Molnar et al. 1993; Rauk and Chiao 2000). Furthermore, IL-1 $\beta$ augmented also the expression of COX2 as well as microsomal PGE synthase-1 (mPGES-1) in pregnant human myometrium (Erkinheimo et al. 2000; Astle et al. 2007). Our previous study demonstrated that IL-1 $\beta$, IL-6 and/or TNF- $\alpha$ stimulated secretion of $\mathrm{PGF}_{2 \alpha}$ and $\mathrm{PGE}_{2}$ as well as expression of COX-2 protein in the chorioamnion (Jana et al. 2008a) and maternal placenta (Jana et al. 2008b) collected during the first third of pregnancy in gilts.

It was demonstrated in rats that the developing inflammatory process of uterus following LPS, peptidoglycan and Escherichia coli infusions is connected with an increase of TNF- $\alpha$ and IL-1 $\beta$ concentrations in peripheral blood (Jana et al. 2005). Moreover, bacterial infection changed PGs production in uterine tissues in many species (Neely et al. 1979; Peter and Bosu 1987; Jana et al. 2007). Also, bacteria and LPS (often used in the intrauterine infection research) stimulate IL-1, IL-6 and/or TNF- $\alpha$ and PGs secretion from rodent myometrium during pregnancy. Both, bacteria- and LPS-induced changes in myometrial PGs production thought effect the contractile activity of the uterus may threaten pregnancy (Hirsch et al. 2006; Anabe et al. 2007).

In livestock including sows, the first third of pregnancy is the most important for successful pregnancy. It was found that in sows between days 20 and 30 of pregnancy a rapid increase in allantoic fluid volume occurred, which is associated with initial expansion of the chorioallantoic membranes and establishment of intimate contact between the placenta and endometrial surface. Moreover, from day 30 to day 70 of pregnancy a gradual increase of amniotic fluid volume was observed. Also, between days 20 and 30 of pregnancy a rapid increase in placental length took place that was continued until day 60 . The number of placental areolae reached a maximum at about 35 to 40 days of pregnancy (Knight et al. 1977). The above processes are regulated by many factors produced locally in the uterus, i.e. PGs. We found earlier that secretion of $\mathrm{PGF}_{2 \alpha}$ and $\mathrm{PGE}_{2}$ by porcine foetal membranes (Jana et al. 2008a) and maternal placenta (Jana et al. 2008b) from the first third of pregnancy is stimulated by cytokines. As to our knowledge there are no data showing the effect of cytokines on PGs release from porcine myometrium, the present study was performed to examine the effect of IL-1 $\beta$, IL- 6 and/or TNF- $\alpha$ on PGF $2 \alpha$ and PGE release by myometrium and on COX-2 protein expression in myometrium collected from pigs on days 25,30 and 40 of pregnancy.

\section{Materials and Methods}

Animals and experimental design

The experimental procedures were approved by the Local Ethics Committee, University of Warmia and Mazury in Olsztyn. Fifteen primiparous crossbred (Large White $\times$ Polish Landrace) gilts (7-8 months, 90-100 kg) were housed on a farm and were checked for oestrus behaviour in the presence of a boar. The gilts were naturally bred at the onset of oestrus (day 0) and then $12 \mathrm{~h}$ and $24 \mathrm{~h}$ later. Three days before slaughter, the animals were transported to the local animal facility and kept in individual stalls under ambient light and temperature. They were fed a commercial grain mixture and tap water ad libitum.

The gilts were paralyzed by electrical shock on days 25,30 and 40 of pregnancy $(n=5$ per day) and exsanguined. The uteri were collected and transported on ice to the laboratory within 3 min. Uterine horns were opened longitudinally on the mesometrial surface and the endometrium (maternal placenta) and perimetrium were separated from the myometrium by careful scraping using a scalpel blade. Next, pieces of myometrium adjacent to maternal placenta were cut and sliced $(100 \mathrm{mg})$ and washed in sterile saline. Individual explants were placed into glass scintillation vials $(20 \mathrm{ml})$ with $2.0 \mathrm{ml}$ Medium-199 containing $0.1 \%$ of bovine serum albumin (BSA), penicillin $(100 \mathrm{IU} / \mathrm{ml})$, streptomycin $(100 \mu \mathrm{g} / \mathrm{ml})$ and amphotericin $(2 \mu \mathrm{g} / \mathrm{ml})$. After $30 \mathrm{~min}$ of preincubation $\left(37^{\circ} \mathrm{C}, 5 \% \mathrm{CO} /\right.$ air $)$, the medium was changed and myometrial slices were incubated in control medium or with addition of 1 or $10 \mathrm{ng} / \mathrm{ml}$ of human IL-1 $\beta$, IL- 6 and TNF- $\alpha$, alone or in combination of all three cytokines at dose 1 or $10 \mathrm{ng} / \mathrm{ml}$ each (Sigma, St. Louis, USA) for additional $16 \mathrm{~h}$. All treatments were performed in triplicates.

The doses of cytokines and time of incubation were based on the results of Pollard and Mitchell (1996). After 
$16 \mathrm{~h}$ of incubation, the media were collected into tubes containing $10 \mu 1$ stabilizing mixture $(0.3 \mathrm{M}$ EDTA, POCH Gliwice, Poland; $1 \%$ aspirin, Polfa, Starogard, Poland) and frozen at $-20{ }^{\circ} \mathrm{C}$ until PGs assay was completed. The slices of myometrium were collected to determine COX-2 protein expression (Western blotting). The tissues were then homogenized on ice with a cold buffer $(50 \mathrm{mmol} / 1$ Tris- $\mathrm{HCl}, \mathrm{pH} 8.0 ; 150 \mathrm{mmol} / 1 \mathrm{NACl} ; 1 \%$ Triton X-100, $10 \mu \mathrm{g} / \mathrm{ml}$ aprotinin, $52 \mu \mathrm{mol} / 1$ leupeptin, $1 \mathrm{mmol} / 1$ pepstatin A, $1 \mathrm{mmol} / 1 \mathrm{EDTA}, 1 \mathrm{~mol} / 1 \mathrm{PMSF})$ and centrifuged $\left(10 \mathrm{~min}, 2500 \times g, 4{ }^{\circ} \mathrm{C}\right)$. The supernatants were centrifuged $\left(1 \mathrm{~h}, 17500 \times g, 4{ }^{\circ} \mathrm{C}\right)$ and pellets were stored at $-80^{\circ} \mathrm{C}$ for further analysis. Protein content was determined by Bradford method (1976).

Enzymoimmunoassay of prostaglandins

The concentrations of $\mathrm{PGF}_{2 \alpha}$ and $\mathrm{PGE}_{2}$ in the medium were measured by a sandwich enzyme immunoassay method (Skarzynski and Okuda 2000). The sensitivity of the assay for $\mathrm{PGF}_{2 \alpha}$ and $\mathrm{PGE}_{2}$ were 0.016 and 0.14 $\mathrm{ng} / \mathrm{ml}$, respectively. Intra- and interassay coefficients of variation for $\mathrm{PGF}_{2 \alpha}$ and $\mathrm{PGE}_{2}$ were 7.9 and $10.4 \%$ and 6.9 and $9.7 \%$, respectively.

Western blotting for COX-2 protein

The expression of COX-2 protein in myometrium was estimated by Western blotting (Jana et al. 2008a). Briefly, the myometrial portions $(20 \mu \mathrm{g})$ were dissolved in sodium dodecyl sulphate (SDS), a gel-loading buffer, heated $\left(95^{\circ} \mathrm{C}, 4 \mathrm{~min}\right)$ and separated by $10 \%$ SDS-polyacrylamide gel electrophoresis. Separated proteins were electroblotted onto $0.45 \mu \mathrm{m}$ nitrocellulose membrane in a transfer buffer. The nonspecific binding sites were blocked by incubation with $5 \%$ fat-free dry milk in TBS-T buffer at room temperature (RT) for $1.5 \mathrm{~h}$. Nitrocellulose membrane was incubated overnight at $4{ }^{\circ} \mathrm{C}$ with rabbit polyclonal anti-COX-2 antibodies (diluted 1:200; Cayman Chemical, USA). COX-2 was detected by incubating the nitrocellulose membrane for $1.5 \mathrm{~h}$ at RT with secondary biotinylated goat anti-rabbit antibodies (diluted 1:3000; Vectastain ABC kit; Vector Laboratories, Inc., Burlingame, CA, USA). Visualization of the immune complex was performed by incubation (2-3 min) with a 3,3'-diaminobenzidine tetrahydrochloride (DAB, Sigma-Aldrich Co., USA) for 10 min. Each analysis was repeated three times. The intensity of COX-2 protein expression was quantitated by measuring optical density using KODAK 1D Image Analysis Software (USA).

Statistical analysis

Experimental data are presented as mean \pm SEM of each experiments performed in triplicates. The in vitro basal $\mathrm{PGF}_{2 \alpha}$ and $\mathrm{PGE}_{2}$ secretion and COX-2 protein expression were analyzed by one-way analysis of variance (ANOVA). The effect of IL-1 $\beta$, IL-6 and TNF- $\alpha$ on PGs and COX-2 content was calculated by one-way analysis of variance (ANOVA) for repeated measures. The Bonferroni test was applied for comparing the mean values (GraphPad PRISM version 4; GraphPAD Software, Inc., San Diego, CA, USA). Differences with probability of $p<0.05$ were considered as significant.

\section{Results}

\section{Basal $\mathrm{PGF}_{2 \alpha}$ and $\mathrm{PGE}_{2}$ secretion and $\mathrm{COX}-2$ protein expression}

The basal myometrial secretion of $\mathrm{PGF}_{2 \alpha}$ collected on day 40 of pregnancy was higher $(p<0.01)$ than on day 25. The increase $(p<0.001)$ in $\mathrm{PGE}_{2}$ secretion was observed on days 30 and 40 of pregnancy compared to day 25 . Moreover, this secretion was higher $(p<$ 0.001 ) on day 40 than on day 30 . The basal COX-2 protein expression in myometrium was higher on days $30(p<0.01)$ and $40(p<0.001)$ compared to day 25 (Table 1). Basal release of $\mathrm{PGE}_{2}$ by myometrial slices was about five-fold higher than that of $\mathrm{PGF}_{2 \alpha}$.

The influence of cytokines on $\mathrm{PGF}_{2 \alpha}$ and $\mathrm{PGE}_{2}$ release

Table 1. Basal secretion of $\mathrm{PGF}_{2 \alpha}$ and $\mathrm{PGE}_{2}$ (ng/ml of medium) and COX-2 protein expression (arbitrary units $\times 10^{3}$ ) in porcine myometrium collected on days 25,30 and 40 of pregnancy.

\begin{tabular}{|c|c|c|c|}
\hline Days of pregnancy & PGF $_{2 a}$ & PGE $_{2}$ & COX-2 \\
\hline 25 & $3.3 \pm 0.4^{\mathrm{a}}$ & $29.4 \pm 1.8^{\mathrm{a}}$ & $7.0 \pm 2.6^{\mathrm{a}}$ \\
\hline 30 & $8.1 \pm 1.8^{\mathrm{ab}}$ & $42.1 \pm 1.2^{\mathrm{b}}$ & $21.5 \pm 3.6^{\mathrm{b}}$ \\
\hline 40 & $14.7 \pm 3.0^{\mathrm{b}}$ & $55.8 \pm 2.5^{\mathrm{c}}$ & $30.2 \pm 3.2^{\mathrm{b}}$ \\
\hline
\end{tabular}

The means in columns marked with different letters (a, b, c) are significantly different $(p<0.01, p<0.001)$.

Higher dose $(10 \mathrm{ng} / \mathrm{ml})$ of IL-1 $\beta$ and IL-6 stimulated $(p<0.05) \mathrm{PGF}_{2 \alpha}$ production by myometrium on day 25 of pregnancy. Similar effect $(p<$ $0.001)$ on $\mathrm{PGF}_{2 \alpha}$ secretion was found on day 30 of pregnancy after the use of both doses of IL-1 $\beta$. On day 40, PGF $_{2 \alpha}$ release by myometrium was increased $(p<0.01)$ by the higher dose of IL-1 $\beta$ and IL-6. PGF ${ }_{2 \alpha}$ secretion was also greater $(p<0.01)$ in response to IL-1 $\beta$ and IL-6 at the higher than at the lower dose (Fig. 1).

On day 25 of pregnancy, the secretion of $\mathrm{PGE}_{2}$ was stimulated $(p<0.05)$ by the 

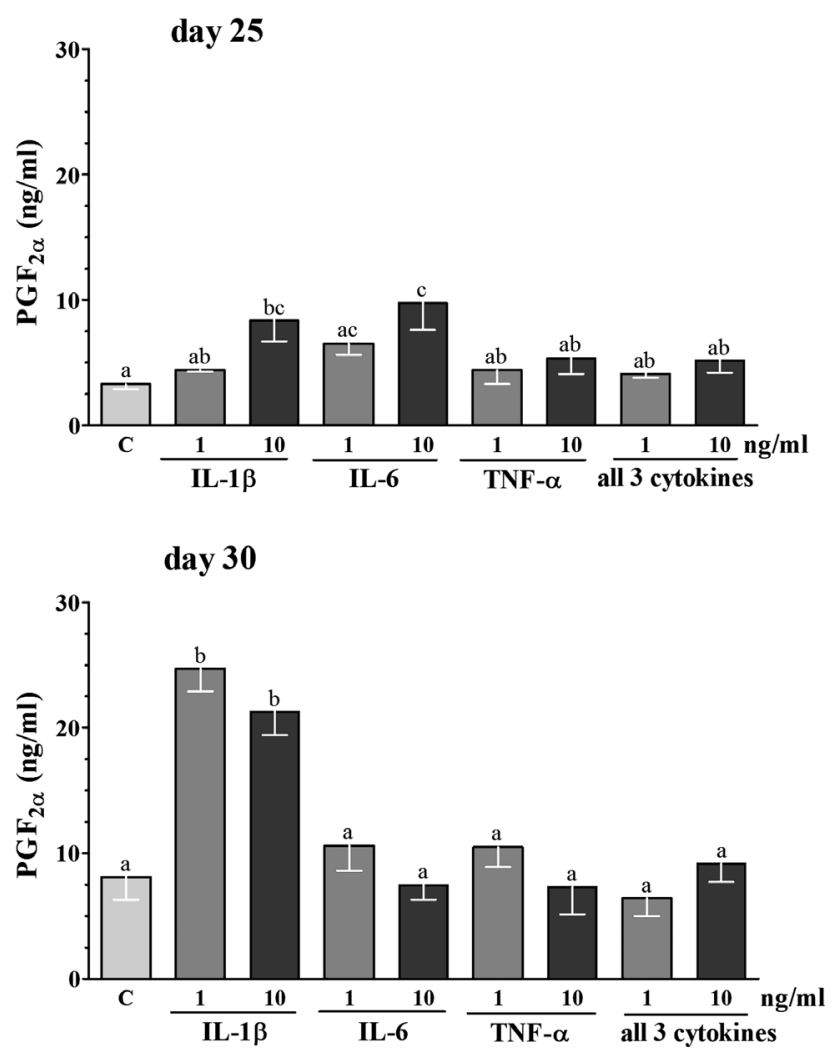

day 40

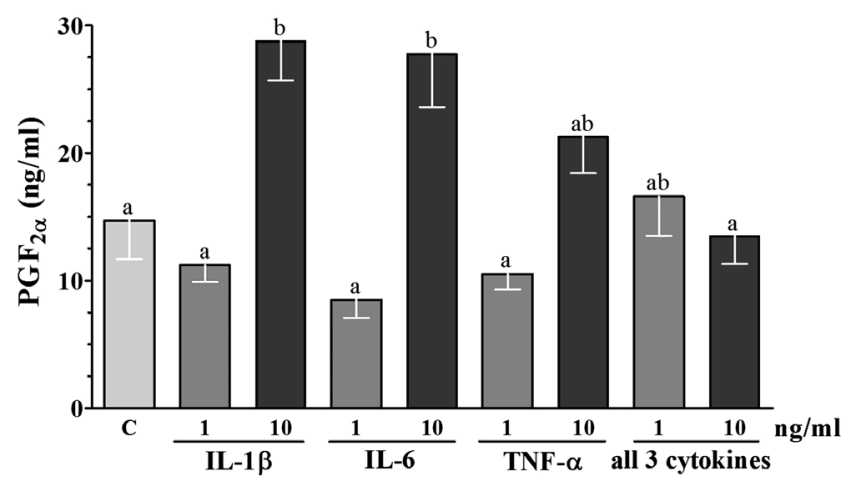

Fig. 1. The effect of IL-1 $1 \beta$, IL- 6 and TNF- $\alpha$ or combination of the three cytokines on PGF ${ }_{2 \alpha}$ secretion (means \pm SEM) by the porcine myometrium collected on days 25,30 and 40 of pregnancy ( $n=5$ per group). Different letters $(\mathrm{a}, \mathrm{b}, \mathrm{c})$ indicate significant differences $(p<0.05-0.001)$.

higher dose of IL-1 $\beta$. The medium content of PGE elevated following the use of IL-1 $\beta$ $(p<0.001)$ and all cytokines in combination at the higher $(p<0.05)$ than the lower dose. $\mathrm{PGE}_{2}$ release by myometrium from 30-day-pregnant gilts augmented after incubation with 


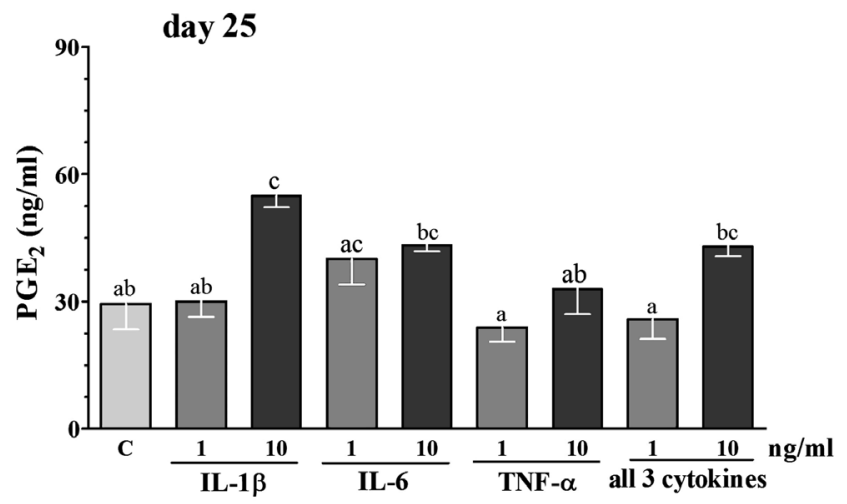

day 30

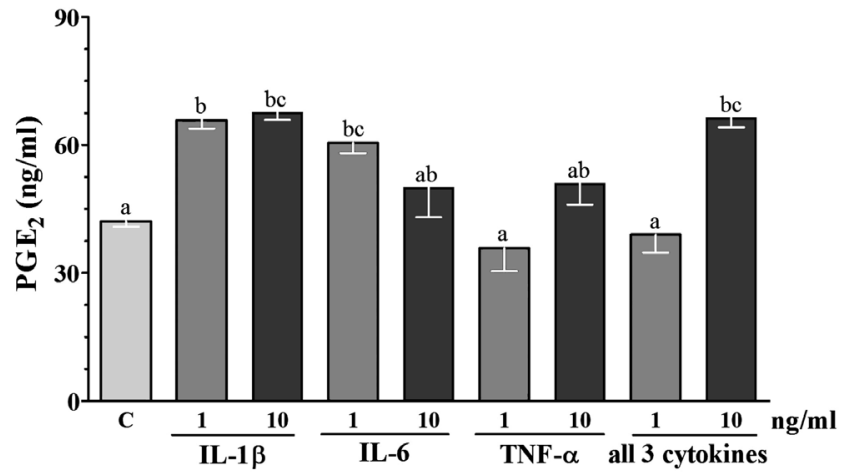

day 40

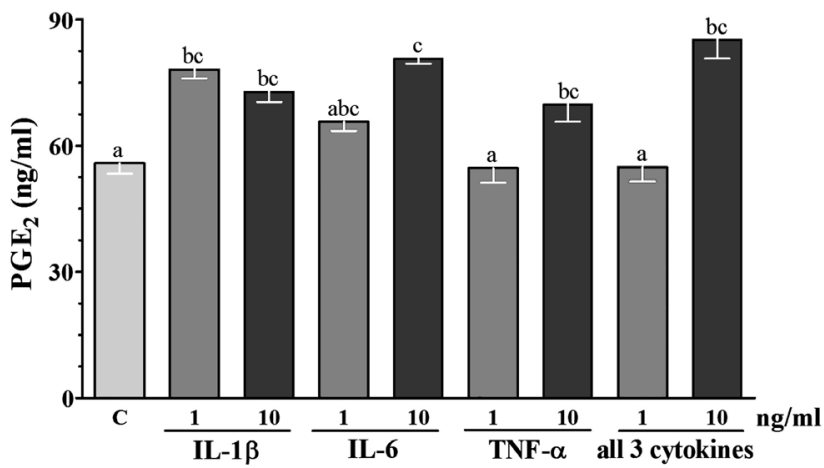

Fig. 2. The effect of IL-1 $\beta$, IL- 6 and TNF- $\alpha$ or combination of the three cytokines on PGE 2 secretion (means \pm SEM) by the porcine myometrium collected on days 25,30 and 40 of pregnancy ( $n=5$ per group). Different letters $(\mathrm{a}, \mathrm{b}, \mathrm{c}, \mathrm{d})$ indicate significant differences $(p<0.05-0.001)$.

both doses of IL-1 $\beta(p<0.001)$, lower dose of IL-6 $(p<0.01)$ and with the three cytokines in the combination applied at the higher dose $(p<0.001)$. The secretion of this PG was higher $(p<0.001)$ in response to all cytokines used at the higher than the lower dose. $\mathrm{PGE}_{2}$ release 
by myometrium from day 40 of pregnancy increased $(p<0.001)$ after the use of both doses of IL-1 $\beta$, higher dose of IL- 6 and TNF- $\alpha$ as well as the three cytokines in the combination applied at the higher dose. $\mathrm{PGE}_{2}$ secretion was higher after treatment with TNF- $\alpha$ $(p<0.01)$ and with the three cytokines in combination $(p<0.001)$ used at the higher dose compared to the lower dose (Fig. 2).

The effect of cytokines on COX-2 protein expression

Myometrial expression of COX-2 protein was demonstrated in gilts on all examined days of pregnancy. The expression of COX-2 protein on day 25 was increased $(p<0.001)$ by the higher dose of IL-1 $\beta$, both doses of IL- 6 and all cytokines in combination used at the higher dose. On this day, the expression of COX-2 was higher after the use of IL-1 $\beta$ $(p<0.05)$ and all cytokines in combination $(p<0.001)$ applied at the higher than the lower dose. Both doses of IL-1 $\beta$, the lower dose of IL- 6 and the three cytokines used together at higher dose augmented $(p<0.05)$ COX-2 protein expression on day 30 . The expression of this enzyme increased $(p<0.05)$ after application of all cytokines in combination at the higher dose compared to their effect at the lower dose. On day 40 of gestation, both doses of IL-1 $\beta(1 \mathrm{ng} / \mathrm{ml}-p<0.05,10 \mathrm{ng} / \mathrm{ml}-p<0.001)$, IL-6 $(p<0.05)$ and TNF- $\alpha$ $(p<0.001)$ and all cytokines in combination used at the higher dose $(p<0.001)$ stimulated the expression of COX-2 protein. The COX-2 expression was higher after treatment with IL-1 $\beta(p<0.01)$, TNF- $\alpha(p<0.001)$ and with the three cytokines together $(p<0.001)$ used at the higher dose compared to the lower dose (Fig. 3).

\section{Discussion}

In the present study, basal as well as IL-1 $\beta$-, IL-6- and TNF- $\alpha$-stimulated secretions of $\mathrm{PGF}_{2 \alpha}$ and $\mathrm{PGE}_{2}$ and expression of COX-2 protein in the myometrium collected during the first third of pregnancy in gilts were evaluated for the first time.

In our experiment, the basal release of $\mathrm{PGF}_{2 \alpha}$ and $\mathrm{PGE}_{2}$ as well as COX-2 protein expression in cultured myometrial slices of 25-, 30- and 40-day-pregnant gilts occurred and the values of studied indicators increased with gestational age, i.e. from day 25 to day 30 and/or 40. Similar phenomenon was observed earlier in pigs for basal production of $\mathrm{PGF}_{2 \alpha}$ and $\mathrm{PGE}_{2}$ as well as COX-2 protein expression in the chorioamnion (Jana et al. 2008a) and maternal placenta (Jana et al. 2008b) from the first third of pregnancy. The basal chorioamnion release of $\mathrm{PGE}_{2}$ enhanced also in pigs during later stages of pregnancy up to day 109 (Rice et al. 1989). The increase in $\mathrm{PGF}_{2 \alpha}$ and $\mathrm{PGE}_{2}$ secretion from myometrium along with the progress of pregnancy observed in the present study may be caused by growing availability of arachidonic acid (AA), a substrate for PGs synthesis, in this tissue. It was previously indicated in pigs that the concentration of this acid significantly increases with advancing gestation in foetal membranes (Ledwozyw and Kadziołka 1989). Moreover, we determined that basal release of $\mathrm{PGE}_{2}$ from myometrium on days 25, 30 and 40 of pregnancy was higher than that of PGF $_{2 \alpha}$. This observation corresponds to the study of Franczak et al. (2006) who also found higher $\mathrm{PGE}_{2}$ secretion porcine myometrium from 14-16 days of pregnancy than $\mathrm{PGF}_{2 \alpha}$. Our work further confirms that porcine myometrium metabolizes AA mainly to $\mathrm{PGE}_{2}$ during gestation.

Generally, we found that IL-1 $\beta$, IL-6 and/or TNF- $\alpha$ stimulated in vitro release of both $\mathrm{PGF}_{2 \alpha}$ and/or $\mathrm{PGE}_{2}$ from porcine myometrium from the first third of pregnancy. These results are consistent with our earlier reports in which we revealed also the stimulatory effect of these cytokines on $\mathrm{PGF}_{2 \alpha}$ and/or $\mathrm{PGE}_{2}$ release from porcine chorioamnion (Jana et al. 2008a) and maternal placenta (Jana et al. 2008b) from the first third of pregnancy. Moreover, Pollard and Mitchell (1996) have demonstrated that IL-1 $\beta$ and TNF- $\alpha$ increased PGF $_{2 \alpha}, \mathrm{PGE}_{2}$ and 6-keto-PGF ${ }_{1 \alpha}$ (the stable metabolite of $\mathrm{PGI}_{2}$ ) 


\section{day 25}
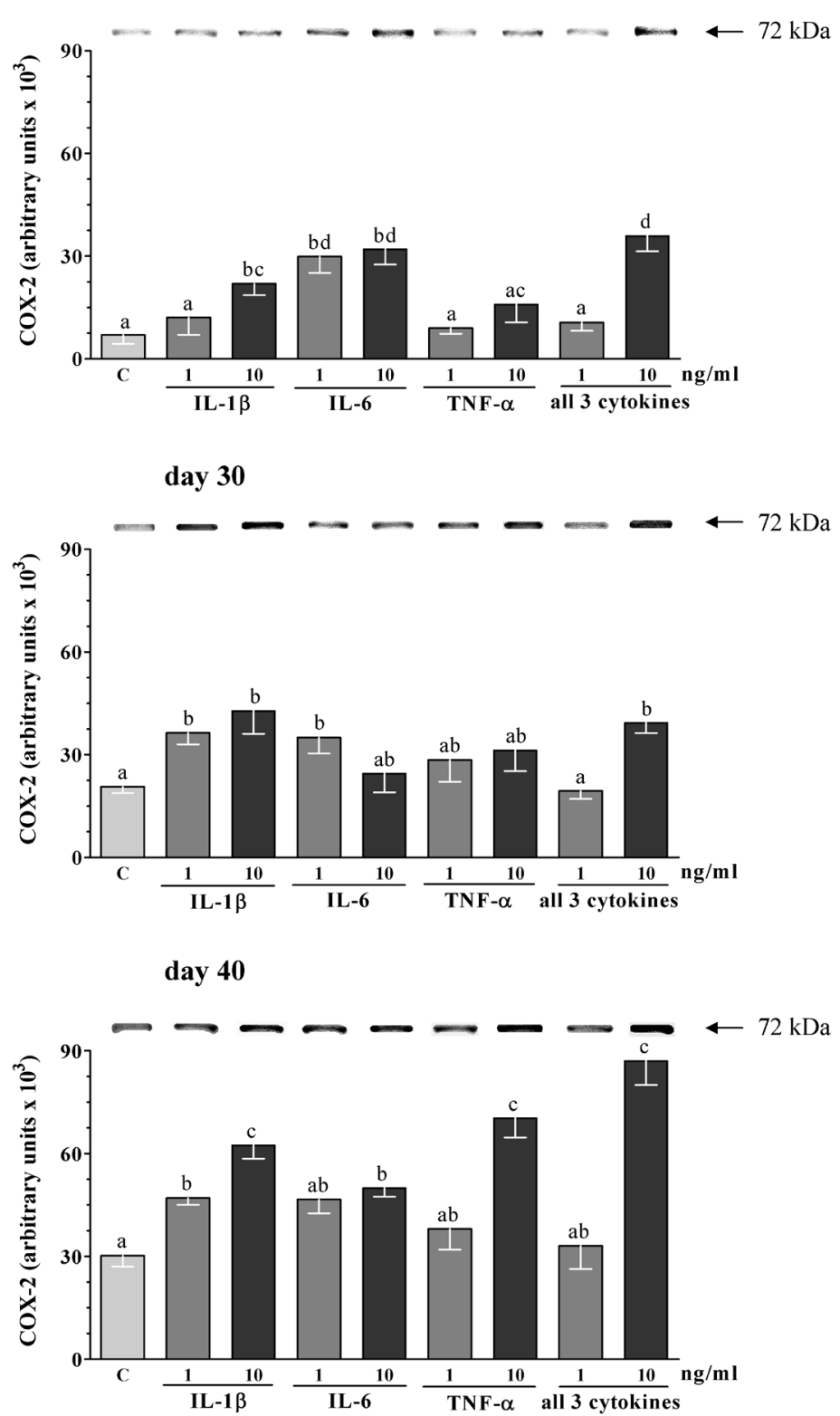

Fig. 3. The effect of IL-1 $\beta$, IL- 6 and TNF- $\alpha$ or combination of the three cytokines on COX-2 protein expression (means \pm SEM) in the porcine myometrium collected on days 25,30 and 40 of pregnancy $(n=5$ per group). Densitometric analysis of bands is presented in arbitrary units. Different letters $(\mathrm{a}, \mathrm{b}, \mathrm{c}, \mathrm{d})$ indicate significant differences $(p<0.05-$ $0.001)$.

secretion from human myometrial tissue from the late period of gestation. In our study the effect of cytokines on the release of $\mathrm{PGF}_{2 \alpha}$ and $\mathrm{PGE}_{2}$ from myometrium, however, depended on cytokine type, treatment dose and day of pregnancy. IL-1 $\beta$ and IL-6 
stimulated release of both PGs from myometrial tissue collected on day 25, 30 and 40 of pregnancy, with the exception of the IL-6 effect on PGF $_{2 \alpha}$ secretion on day 30. In turn, TNF- $\alpha$ increased $\mathrm{PGE}_{2}$ release only by myometrium of 40 -day-pregnant gilts. The different ability of cytokines to release PGs in several days of gestation may arise from diverse expression of receptors for particular cytokines in myometrium during pregnancy. To our knowledge, there are only data showing the expression of receptors for IL-1 and IL-8 in human myometrium at term (Hatthachote and Gillespie 1999). As we demonstrated here, cytokines used individually (at a dose of 1 and $/$ or $10 \mathrm{ng} / \mathrm{ml}$ ) increased more often the output of $\mathrm{PGE}_{2}$ compared to $\mathrm{PGF}_{2 \alpha}$ from myometrial tissues. Although the reason for this situation is unclear, we speculate that cytokines could exert a more potent effect on expression of PGES than on PGF synthase. This hypothesis may be partially confirmed by studies showing that the PGES-1 mRNA concentration in myometrial cells of pregnant women correlated considerably with that of IL-1 $\beta$ (Sooranna et al. 2006). Results of the present study demonstrate that generally, the quantity of $\mathrm{PGF}_{2 \alpha}$ and $\mathrm{PGE}_{2}$ released is not dependent on the dose of cytokines. In a few cases, however, release of PGs was higher after the use of cytokine/s at the dose of 10 compared to $1 \mathrm{ng} / \mathrm{ml}$. A dose-dependent increase in the production of PGI and $\mathrm{PGE}_{2}$ in response to IL-1 was previously determined in human myometrial cells (Todd et al. 1996). Similarly, human myometrial cells responded to IL-1 and TNF- $\alpha$ treatment with release of AA (Molnar et al. 1993). Moreover, we did not find a significant increase in PGs secretion from myometrium after cytokine application in combination, with the exception of the $\mathrm{PGE}_{2}$ release by tissue of 30- and 40-day-pregnant gilts. This may due to a post-receptor convergence on the same secondary signal pathways. Such mechanism was described for both TNF- $\alpha$ - and IL-1-induced stimulation of the human immunodeficiency virus enhancer which occurs through the activation of $\mathrm{NF}-\kappa \mathrm{B}$ (Osborn et al. 1989). It is possible that similar signalling pathways are involved in activation of COX-2 or other PG-synthesizing enzymes by particular cytokines.

Both basal and cytokine-stimulated myometrial secretion of $\mathrm{PGE}_{2}$ observed in our study suggests that this tissue may be an additional important source of $\mathrm{PGE}_{2}$ close to endometrium, influencing corpora lutea protection during pregnancy in pigs (Christenson et al. 1994). Moreover, the augmentation in myometrial $\mathrm{PGE}_{2}$ release in response to cytokines observed on days 25, 30 and 40 of pregnancy is positively correlated with the initial expansion of chorioamniotic and chorioallantoic membranes, establishment of intimate contact between both maternal and foetal parts of placenta, an increase in placental size and with the initiation and/or elevation of amniotic/allantoic fluid accumulation (Knight et al. 1977). This observation allows to suppose also that $\mathrm{PGE}_{2}$ acting via relaxatory $\mathrm{EP}_{2}$ receptors in porcine myometrium may suppress the contractile activity of this tissue contributively to the maintenance of uterine quiescence during pregnancy, as was previously found in women (BrodtEppley and Myatt 1999) and rats (Myatt and Lye 2004).

It is important to underline that intra-uterine infections in women and laboratory animals cause the release of larger quantities of TNF- $\alpha$, IL-1 $\beta$ and IL- 6 and changes in PGs synthesis in gestational tissues leading inevitably to adversity of gestation (Dudley 1997). Splichalova et al. (2004) reported that in vivo intra-amniotic administration of Escherichia coli during the second half of gestation in pigs induces a high concentration of TNF- $\alpha$ in amniotic fluid. LPS was also found to increase, with the involvement of mitogen-activated protein (MAP) kinases, TNF- $\alpha$ and IL-10 production in human choriodecidua (Shoji et al. 2007). Moreover, the myometrial cells from pregnant women with intra-uterine infections in response to IL-1 $\beta$ and TNF- $\alpha$ produced more $\mathrm{PGF}_{2 \alpha}$ and $\mathrm{PGE}_{2}$ than those from patients without infections (Pollard and Mitchell 1996). The effect of these cytokines on PG production in myometrium 
during infection may be modified by immunosuppressive cytokines, for example, IL-4, IL-10 and transforming growth factor- $\beta$ (Dudley 1997). Additionally, TNF- $\alpha-$ stimulated PGs synthesis in myometrium may be also dependent on the expression of TNF- $\alpha$ converting enzyme (Hung et al. 2006). Thus it is possible that excess of $\mathrm{PGF}_{2 \alpha}$ secretion in porcine myometrium may be harmful for developing embryos and foetuses via disturbances in corpus luteum function (Christens on et al. 1994). On the other hand, $\mathrm{PGF}_{2 \alpha}$ produced at a larger amount in the myometrium of pregnant gilts with intra-uterine infections may also result in the expulsion of dead foetuses from the uterus. A similar effect may also exert $\mathrm{PGE}_{2}$ acting via contractile receptors - $\mathrm{EP}_{1}$ and $\mathrm{EP}_{3}$ (Brodt-Eppley and Myatt 1999; Myatt and Lye 2004).

In the present study, an increase in $\mathrm{PGF}_{2 \alpha}$ and/or $\mathrm{PGE}_{2}$ secretion from myometrium was accompanied by an augmentation in COX-2 protein expression. Our results are in agreement with data by Astle et al. (2007) who found an increase in the PGs release and COX-2 expression in myometrial cells of non-pregnant women after stimulation with IL1. In one case, however, we observed on day 25 of pregnancy an enhancement in COX-2 protein expression without an increase in $\mathrm{PGF}_{2 \alpha}$ and/or $\mathrm{PGE}_{2}$ (Figs 1-3). This suggests that an up-regulation of COX-2 protein expression may be connected with augmentation in $\mathrm{PGI}_{2}$ production, as indicated earlier in human myometrium in response to IL-1 $\beta$ and TNF- $\alpha$ (Pollard and Mitchell 1996).

In conclusion, the presented data demonstrate that IL- $1 \beta$ and IL-6 stimulated secretion of $\mathrm{PGF}_{2 \alpha}$ and $\mathrm{PGE}_{2}$ by porcine myometrium collected on days 25,35 and 40 of pregnancy, except for the influence of IL-6 on PGF $_{2 \alpha}$ release on day 35 . TNF- $\alpha$ resulted only in the increase of $\mathrm{PGE}_{2}$ secretion by myometrium in 40-day-pregnant gilts. However, further studies should be performed to elucidate the mechanism of PG production in response to cytokines. Our data suggest also that locally PGs produced in myometrium influencing the uterine contraction activity may be important for the maintenance of myometrial quiescence during pregnancy.

\section{References}

Anabe H, Okawa T, Sugawara N, Takahashi H, Sato A, Vadernikow YP, Saade GR, Garfield RE 2007: Influence of progesterone on myometrial contractility in pregnant mice treated with lipopolysaccharide. J Obstet Gynecol Res 33: 765-771

Ashworth MD, Ross JW, Hu J, White FJ, Stein DR, Desilva U, Johnson GA, Spencer TE, Geisert RD 2006: Expression of porcine endometrial prostaglandin synthase during the estrous cycle and early pregnancy, and following endocrine disruption of pregnancy. Biol Reprod 74: 1007-1015

Astle S, Newton R, Thornton S, Vatish M, Slater DM 2007: Expression and regulation of prostaglandin E synthase isoforms in human myometrium with labour. Mol Hum Reprod 13: 69-75

Bradford MM 1976: A rapid and sensitive method for the quantitation of microgram quantities of protein utilizing the principle of protein-dye binding. Analytical Biochem 72: 248-254

Brodt-Eppley J, Myatt L 1999: Prostaglandin receptors in lower segment myometrium during gestation and labor. Obstet Gynecol 93: 89-93

Chabot V, Lambert RD, Laforest JP, St-Jaques S, MatteJJ, Guay F, Pallin MF, Lessard M 2004: Effect of oestrous cycle and early pregnancy on uterine production and expression of immune regulatory factors in gilts. Anim Reprod Sci 81: 137-149

Christenson LK, Farley DB, Anderson LH, Ford SP 1994: Luteal maintenance during early pregnancy in the pig: role for prostaglandin E2. Prostaglandins 47: 61-75

Dong Y.L, Yallampalli C 2000: Pregnancy and exogenous steroid treatments modulate the expression of relaxant $\mathrm{EP}_{2}$ and contractile FP receptors in the rat uterus. Biol Reprod 62: 533-539

Dudley DJ 1997: Pre-term labor: an intra-uterine inflammatory response syndrome? J Reprod Immunol 30: 93-109

Erkinheimo TL, Saukkonen K, Narko K, Jalkanen Ylikorkala O, RistimakiA2000: Expression of cyclooxygenase-2 and prostanoid receptors by human myometrium. J Clin Endocrinol Metab 85: 3468-3475

Franczak A, Kotwica G, Kurowicka B, Oponowicz A, Wacławek-Potocka I, Petroff BK 2006: Expression of enzymes of cyclooxygenase pathway and secretion of prostaglandin E2 and F2alpha by porcine myometrium during luteolysis and early pregnancy. Theriogenology 15: 1049-1056

Hatthachote P, Gillespie JI 1999: Complex interactions between sex steroids and cytokines in the human pregnant myometrium: evidence for an autocrine signaling system at term. Endocrinology 40: 2533-2540 
Hirsch E, Filipovich Y, Mahendroo M 2006: Signaling via the type I IL-1 and TNF receptors is necessary for bacterially induced preterm labor in a murine model. Am J Obstet Gynecol 194: 1334-1340

Hung TH, Chen SF, Hsu JJ, Hsieh CC, Hsueh S, Hsieh TT 2006: Tumor necrosis factor-alpha converting enzyme in human gestational tissues from pregnancies complicated by chorioamniotis. Placenta 27: 996-1006

Hunt JS 1993: Expression and regulation of the tumor necrosis factor- $\alpha$ in the female reproductive tract. Reprod Fertil Dev 5: 141-153

Jana B, Kucharski J, Jedlińska-Krakowska M, Wolińska-Witort E 2005: The effect of intrauterine infusion of inflammation-provoking factors on proinflammatory cytokines and hormones in rat peripheral blood. Polish $\mathrm{J}$ Vet Sci 4: 275-282

Jana B, Kucharski J, Dzienis A, Deptuła K 2007: Changes in prostaglandin production and ovarian function in gilts during endometritis induced by Escherichia coli infection. Anim Reprod Sci 97: 137-150

Jana B, Kozłowska A, Andronowska A, Jedlińska-Krakowska M 2008a: The effect of tumor necrosis factor- $\alpha$ $(\mathrm{TNF}-\alpha)$, interleukin (IL)-1 $\beta$ and IL-6 on chorioamnion secretion of prostaglandins $\left(\mathrm{PG} \mathrm{F}_{2 \alpha}\right.$ and $\mathrm{E}_{2}$ in pigs. Reprod Biol 8: 57-68

Jana B, Koszykowska M, Andronowska A 2008b: The effect of tumor necrosis factor- $\alpha$ (TNF- $\alpha$ ), interleukin (IL) $-1 \beta$ and IL-6 on prostaglandins $(\mathrm{PG}) \mathrm{F}_{2 \alpha}$ and $\mathrm{E}_{2}$ secretion from maternal placenta in pigs. Polish J Vet Sci 4: $315-322$

Kijubu DA, Fletcher BS, Varnum BC, Lim RW, Uerschman UR 1991: TIS10, a phorbol ester tumor promoterinducible mRNA from Swiss 3T3 cells, encodes a novel prostaglandin/cyclooxygenase homologue. J Biol Chem 266: 12866-12872

Kim YJ, Ahn JJ, Woo BH 1998: The effect of cytokine mediators on prostaglandin inhibition by human decidual cells. Am J Obstet Gynecol 179: 146-149

Knight JW, Bazer FW, Thacher WW, Franke DE, Wallace DE 1977: Conceptus development in intact and unilaterally hysterectomized-ovariectomized gilts: interrelations among hormonal status, placental development, fetal fluids and fetal growth. J Anim Sci 44: 620-637

Korita D, Itoh H, Sagawa N, Yura S, Yoshida M, Kakui K, Takemura M, Nuamah MA, Fujii S 2004: Cyclic mechanical stretching and interleukin-1alpha synergistically up-regulate prostacyclin secretion in cultured uterine myometrial cells. Gynecol Endocrinol 18: 130-137

Ledwozyw A, Kadziołka A 1989: Swine fetal membrane and myometrium lipids in ontogenesis (in Polish). Pol Arch Weter 29: 93-105

Lee SH, Soyoola E, Chanmungan P, Hart S, Sun W, Zhong H, Liou S, Simmons D, Hwang D 1992: Selective expression of mitogen-inducible cyclooxygenase in macrophagas, stimulated with lipopolysaccharide. J Biol Chem 267: 25934-25938

Molnar M, Romero R, Hertelendy F 1993: Interleukin-1 and tumor necrosis factor stimulate arachidonic acid release and phospholipid metabolism in human myometrial cells. Am J Obstet Gynecol 169: 825-829

Myatt L, Lye SJ 2004: Expression, localization and function of prostaglandin receptors in myometrium. Prostaglandins Leukot Essent Fatty Acids 70: 137-148

Neely DP, Kindahl H, Stabenfeldt GH, Edqvist LE, Hughes JP 1979: Prostaglandin release pattern in the mare: physiological, pathophysilogical, and therapeutic responses. J Reprod Fertil Suppl 27: 181-189

Osborn L, Kunkel S, Nabel GI 1989: TNF- $\alpha$ and IL-1 stimulate the human immunodeficiency virus enhancer by activation of the NF- $\kappa$ B. Proc Natl Acad Sci USA 86: 2336-2340

Peter AT, Bosu WTK 1987: Effects of intrauterine infection on the function of the corpora lutea formed after first postpartum ovulation in dairy cows. Theriogenology 127: 593-609

Pollard JK, Mitchell MD 1996: Intrauterine infection and the effects of inflammatory mediators on prostaglandin production by myometrial cells from pregnant women. Am J Obstet Gynecol 174: 682-686

Rauk PN, Chiao JP 2000: Interleukin-1 stimulates human uterine prostaglandin production through induction of cyclooxygenase-2 expression. Am J Reprod Immunol 43: 152-159

Rice GE, Christensen P, Dantzer V, Skadhauge E 1989: Gestational profile of prostaglandin E2 synthesis by porcine placenta and fetal membranes. Eicosanoids 2: 235-240

Ross JW, Malayer JR, Ritchey JW, Geisert RD 2003: Characterization of the interleukin-1beta system during porcine trophoblastic elongation and early pregnant attachment. Biol Reprod 69: 1251-1259

Sato TA, Gupta DK, Keelan JA, Marvin KW, Mitchell MD 2001: Expression of interleukin-1beta mRNA in murine uterine and gestational tissues: relationship with gestational age. Am J Reprod Immunol 46: 413-419

Shoji T, Yoshida S, Mitsunari M, Miyake N, Tsukihara S, Iwabe T, Harada T, Terakawa N 2007: Involvement of p38 MAP kinase in lipopolysaccharide-induced production of pro- and anti-inflammatory cytokines and prostaglandin E(2) in human choriodecidua. J Reprod Immunol 75: 82-90

Skarzynski DJ, Okuda K 2000: Different actions of noradrenaline and nitric oxide on the output of prostaglandins and progesterone in cultured bovine luteal cells. Prostaglandins Other Lipid Mediat 60: 35-47

Sooranna SR, Grigsby PL, Engineer N, Liang Z, Sun K, Myatt L, Johnson MR 2006: Myometrial prostaglandin $\mathrm{E}_{2}$ synthetic enzyme mRNA expression: spatial and temporal variations with pregnancy and labour. Mol Hum Reprod 12: 625-631

Splichalova A, Spihal I, Trebichavsky I, Hojna H 2004: Expression of inflammatory markers in pig amnion after intraamniotic infection with nonpathogenic or enteropathogenic Escherichia coli. Folia Microbiol 49: 751-756 
Stanfield KM, Bell RR, Lisowski AR, English ML, Saldeen SS, Khan KN 2003: Expression of cyclooxygenase-2 in embryonic and fetal tissues during organogenesis and late pregnancy. Birth Defects Res Part A Clin Mol Teratol 67: $54-58$

Todd HM, Dundoo VL, Gerber WR, Cwiak CA, Baldassare JJ, Hertelendy F 1996: Effect of cytokines on prostaglandin E2 and prostacyclin production in primary cultures of human myometrial cells. J Matern Fetal Med 5: 161-167

Young A, Thomson AJ, Ledingham M, Jordan F, Greer IA, Norman JE 2002: Immunolocalization of proinflammatory cytokines in myometrium, cervix, and fetal membranes during human parturition at term. Biol Reprod 66: 445-449

Yu Z, Gordon JR, Kendall J, Tacker PA 1998: Elevation in tumor necrosis factor-alpha (TNF-alpha) messenger RNA levels in the uterus of pregnant gilts after oestrogen treatment. Anim Reprod Sci 50: 57-67 